\title{
POTENSI MINYAK ATSIRI DARI TRIKOMA GLANDULAR Hyptis suaveolens (L.) Poit DALAM MENGHAMBAT PERTUMBUHAN Colletotrichum gloeosporioides (Penz) Sacc. PENYEBAB PENYAKIT ANTRAKNOSA PADA CABAI
}

\begin{abstract}
ABSTRAK
Antraknosa adalah salah satu penyakit pada tanaman cabai yang disebabkan oleh Colletotrichum gloeosporioides (Penz) Sacc. Selama ini pengendaliannya dilakukan dengan penyemprotan fungisida sintetis yang meninggalkan residu berbahaya bagi kesehatan manusia. Oleh karena itu perlu dicari fungisida lain yang dapat diperoleh dari tumbuhan. Telah dilakukan penelitian mengenai potensi minyak atsiri dari trikoma glandular $H$. suaveolens (L.) Poit. dalam menghambat pertumbuhan C. gloeosporioides (Penz) Sacc. penyebab penyakit antraknosa pada cabai. Penelitian dilakukan dari bulan Februari 2012 sampai bulan September 2013. Minyak atsiri yang diperoleh dari $H$. suaveolens (L.) Poit. disekresikan oleh trikoma glandular tipe peltate dan capitate. Terdapat perbedaan komponen minyak atsiri H. suaveolens (L.) Poit. antara daun muda dan daun dewasa. Jumlah komponen pada daun muda adalah 50 komponen, sedangkan pada daun dewasa hanya 37 komponen. Komponen utama pada daun muda H.suaveolens (L.) Poit adalah $\beta$-caryophyllene $(34,65 \%)$, germacrene-D $(10,32 \%), \alpha$-bergamotene $(6,56 \%)$, rimuene $(6,46 \%)$, dan $\alpha$-copaene $(5,94 \%)$, kemudian pada daun dewasa adalah $\beta$-caryophyllene $(23,53 \%)$, germacrene-D $(9,52 \%), \beta$-elemene $(6,53 \%)$ dan rimuene $(13,13)$. Namun minyak atsiri yang berasal dari daun muda maupun daun dewasa sama-sama dapat menghambat pertumbuhan $C$. gloeosporioides (Penz) Sacc. dengan persentase daya hambat $\geq 50 \%$ tetapi $<68 \%$ yang termasuk ke dalam kelompok fungitoksisitas sedang.
\end{abstract}

Kata kunci: Hyptis suaveolens (L.) Poit, Colletotrichum gloeosporioides (Penz) Sacc gloeosporioides, trikoma glandular, minyak atsiri 